\title{
Design and directed evolution of genetically encoded cGMP sensors
}

\author{
Arne Fabritius*, Oliver Griesbeck \\ From 7th International Conference on cGMP Generators, Effectors and Therapeutic Implications \\ Trier, Germany. 19-21 June 2015
}

Imaging cGMP transients in in vivo models is very challenging and therefore requires probes that are highly optimized for this task. Several key factors are to be considered while developing such a biosensor: affinity and dynamic range - to cover physiologically relevant concentration ranges, sensitivity - to facilitate meaningful imaging of small variations in concentration, and overall brightness and stability - to increase signal/noise ratio and provide comparable results through a variety of compartments and tissues.

We seek to generate a robust genetically encoded FRET-sensor for cGMP imaging. Our approach adapts protocols that our lab developed and has already successfully applied in the development of $\mathrm{Ca}^{2+}$ biosensors $[1,2]$. This method combines an initial rational design approach with several iterations of directed evolution. Rational design of these probes supplies prototypes, which are turned into partially randomized libraries. These libraries are subsequently screened in E.coli by means of a semiautomatic high throughput process. Promising candidates are biochemically characterized in vitro and later on tested in cell culture.

Initial results already show substantial improvements over existing cGMP biosensors and indicate, that the success in the field of $\mathrm{Ca}^{2+}$ imaging can be repeated for cGMP.

Published: 2 September 2015

\section{References}

1. Thestrup T, Litzlbauer J, Bartholomaus I, Mues M, Russo L, Dana H, et al: Optimized ratiometric calcium sensors for functional in vivo imaging of neurons and T lymphocytes. Nat Methods 2014, 11(2):175-182.

2. Litzlbauer J, Schifferer M, Ng D, Fabritius A, Thestrup T, Griesbeck O: Large Scale Bacterial Colony Screening of Diversified FRET Biosensors. PLOS One 2015, 10(6):e0119860.

* Correspondence: afabritius@neurompg.de

Max Planck Institute of Neurobiology, Martinsried, Bayern, Germany
doi:10.1186/2050-6511-16-S1-A48

Cite this article as: Fabritius and Griesbeck: Design and directed evolution of genetically encoded cGMP sensors. BMC Pharmacology and Toxicology 2015 16(Suppl 1):A48.
Submit your next manuscript to BioMed Central and take full advantage of:

- Convenient online submission

- Thorough peer review

- No space constraints or color figure charges

- Immediate publication on acceptance

- Inclusion in PubMed, CAS, Scopus and Google Scholar

- Research which is freely available for redistribution

Submit your manuscript at www.biomedcentral.com/submit
() Biomed Central 